\title{
Studying The Effect of Low Temperature on Adhesion Strength of Internal Lining Coating for Steel Liquid Gas Storage Tanks
}

Dr. Niveen Jamal Abdul kader ${ }^{*}$, Dr. Hussain mohammed Yousif ${ }^{* *}$, Dr. Ahmed Mudafer

Hashim $^{* * *}$, Dr. Ahmed Ameed Zainalabdeen ${ }^{*}$, Aseel Mahmood Abd Allah*

*Dep. of Materials Engineering, University of Technology, Baghdad /Iraq

${ }^{* *}$ State Company for Steel Industries, Ministry of industry \& mineral, Baghdad /Iraq

${ }^{* * *}$ Dep. of Mechanical Engineering, Al-Qadisiyah University, Qadisiyah /Iraq

Corresponding Author E-mail: niveen.alwandawy@yahoo.com

\section{Abstract:}

Metal storage tanks for liquid gas are unstable at low temperature (below zero degree centigrade), because the metal tends to be brittle and susceptible to crack. In this research studying some physical properties such as shrinkage, adhesion force and coating layer thickness of aluminum powder with ethyl silicate as a binder were performed. The results shown, that the coating with such layer has excellent resistance to low temperature and impermeable to liquid gas for example, propane, methane and nitrogen a suitable coating layer thickness is $(5 \mathrm{~mm})$. The data and results were optimized by using Taguchi / ANOVA Technique.

دراسة تأثير درجة الحرارة المنخفضة متانة الالتصاق لطبقة التبطين الداخلي لحاويات خزن الغاز السائل المصنوعة من الفولاذ

الخلاصة

حاويات خزن الغاز السائل المعدنية تكون غير مستقرة بدرجات الحرارة المنخفضة (تحت الصفر المئوي)، لان المعدن يميل

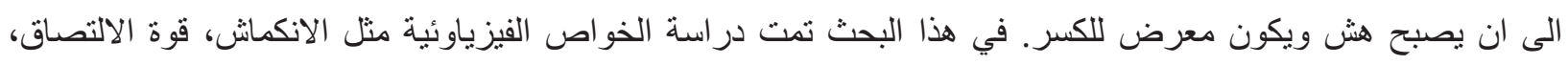

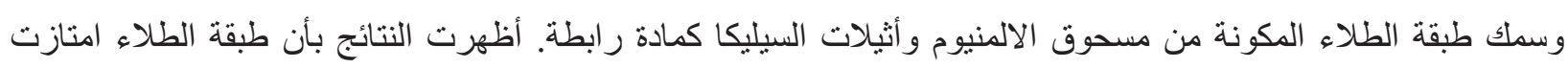
بمقاومة ممتازة في درجات الحرارة المنخفضة وأنها غير مسامية للغازات السائلة مثل البروبان، الميثان و النيتروجين. ان ان أفضل سمك لطبقة الطلاء (5 ملم). أجريت عملية الامثلية الرياضية للبيانات و النتائج باستخدام تقنية تاكوجي/ أنوفا. 


\section{$\underline{\text { Introduction }}$}

Paints and coatings of all types are widely used to provide color and pleasing aesthetics, and to prevent deterioration of the underlying substrate when exposed to various environments. Besides protection and beauty, however, coatings provide light reflectivity, camouflage surfaces, reflect and absorb heat, and provide a variety of other functions [1].

However, in order to provide these functions, the protective coating must remain intact and adherent on the surface to which it has been applied. The vast majority of all protective coatings perform admirably until an old age, at which time natural deterioration and degradation occur. However, a coating can fail prematurely, preventing its aforementioned functions from being realized [2].

The major reasons for the occurrence of corrosion usually are poor or deficient surface preparation, or insufficient coating thickness. There are, of course, many other reasons why coatings deteriorate and corrosion occurs [3, 4]:

- A paint or coating is incorrectly formulated or manufactured by the coating supplier.

- An unsuitable coating is specified for a given environment.

- Environmental conditions are different than that understood by the specifier.

- There is improper, or insufficient, mixing of the coating at the time of application.

- There are adverse ambient conditions when the coating system is applied.

- The drying and/or curing of the coating after application is impaired.

- There is chemical, physical, and/or mechanical damage to the coating system during exposure.

These causes of failure are relevant only when a premature coating failure occurs.

Instead, most protective coatings are successfully specified and applied to a properly prepared surface to the appropriate thickness [5].

These coatings perform as intended, but over time deteriorate and lose their protective or aesthetic function as a result of old age, combined with exposure to aggressive environments. There are a variety of environmental stresses that combine to degrade coatings exposed in a service environment $[6,7]$.

The aim of this paper suggests Aluminum powder mixed with ethyl silicate as a binder to make using layer on inside surface area of a liquid gas steel container. 
There fore the multi-layered container with the Al powder and ethyl silicate intermediate wall is introduced which promises both the thickness reduction of the tank outer wall and higher coating storage tanks.

The coating is responsible for supplying a certain amount of strength and good adhesion to the tank. When the container is filled with liquid gas, it decreases the temperature.

The main property of this compound is to decrease the porosity and create an additional support to the outer wall in encountering the low temperature inside.

In this sense it can also be stated that the tank adjusts its own strength and lower factor of safeties than the standards may be applied as well. Furthermore, this wall is going to reduce the total tank weight since it will be made of lightweight materials. At last but not at least, the out wall is expected to reduce the permeation rate of liquid gas through the walls to the outside, so the leakages can be significantly reduced.

\section{Experimental Procedures}

Samples of (low carbon steel) were used with dimension $(10 * 40 * 1) \mathrm{mm}$. Coating process was performed after samples primary and secondary preparation, by using pressure spraying system [8].

Coating layer includes (50 micron) aluminum powder mixed with ethyl silicate as a binder shown in tables ( 1 and 2 ) respectively.

Table (1) The composition of Commercial Purity aluminum (AA 1060).

\begin{tabular}{|c|c|c|c|c|c|c|}
\hline $\mathrm{Al}$ & $\mathrm{Si}$ & $\mathrm{Fe}$ & $\mathrm{Ti}$ & $\mathrm{V}$ & $\mathrm{Cu}$ & $\mathrm{Mn}$ \\
\hline 99.76 & 0.08 & 0.15 & 0.001 & 0.007 & 0.001 & 0.003 \\
\hline
\end{tabular}

Table (2) The composition of ethyl silicate

\begin{tabular}{|c|c|c|}
\hline $\mathrm{SiO}_{2}$ & $\begin{array}{c}\text { ETHYL } \\
\text { ALCOHOL }\end{array}$ & water \\
\hline $41 \%$ & $12 \%$ & Rem. \\
\hline
\end{tabular}

Form of ethyl silicate having an $\mathrm{Sio}_{2}$ contet of above $50 \%$ comprising reacting apartally condensed ethyl silicate having an si02 content of about $40 \%$ with an aqueous ethyl al cohol containing less than $11 \%$ byweight of water based upon , said water being sufficient to partially condense said ethy silicate to an si02 content of above $50 \%$. 
Three factors and their effects on the adhesion force were studied. The factors and their levels are illustrated in table (3).

Table (3) Factors and their levels

\begin{tabular}{|c|c|c|c|}
\hline Factor & Level 1 & Level 2 & Level 3 \\
\hline $\mathrm{A} 1 \%$ & 15 & 30 & 45 \\
\hline Coating Thickness mm & 1 & 3 & 5 \\
\hline Temperature $\mathrm{C}^{0}$ & -5 & -10 & -15 \\
\hline
\end{tabular}

Each sample after coating has been bend by using U- bending tool, The purpose of bending process is to expose the outside surface of the sample (i.e coating layer) to tension as shown in figure (1). Each sample after bending were locating in cooling chamber at required temperature. Taguchi orthogonal array method was used to determine design of experiment [9]. Nine experiments were run as shown in table (4).

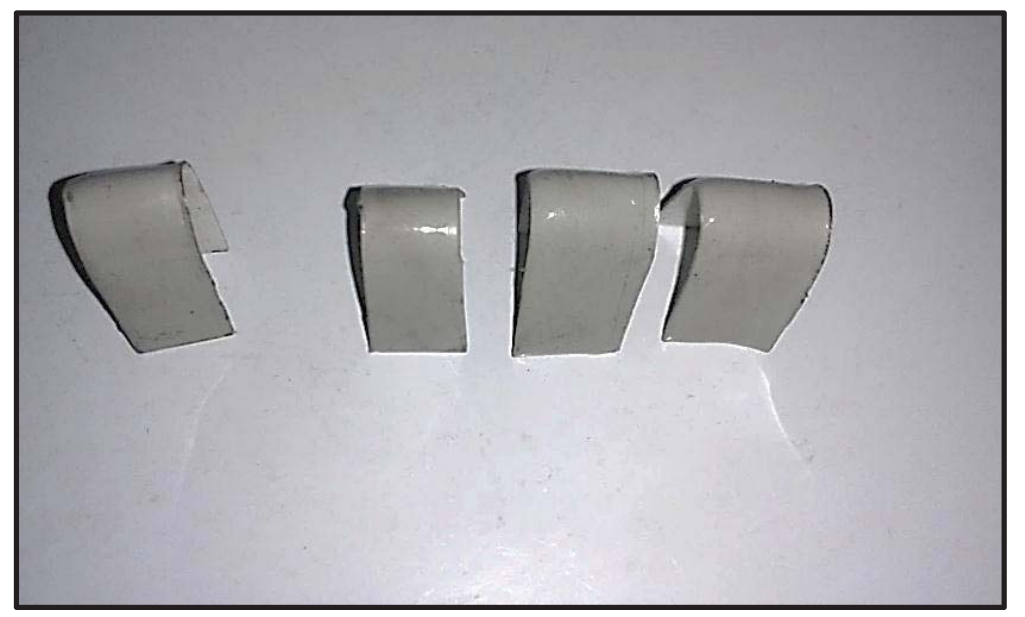

Fig. (1) Coated samples after bending operation. 
Table (4) Design of Experiments via Technique

\begin{tabular}{|c|c|c|c|c|c|c|c|c||}
\hline \hline & C1 & C2 & C3 & C4 & C5 & C6 & C7 & C8 \\
\hline Al\% & $\begin{array}{c}\text { Coating Thic. } \\
(\mathrm{mm})\end{array}$ & $\begin{array}{c}\text { Temp. } \\
(\mathrm{C})\end{array}$ & Trial 1 & Trail 2 & Trail 3 & Mean & $\begin{array}{c}\text { S/N } \\
\text { ratio }\end{array}$ \\
\hline 1 & 15 & 1 & -5 & 4.1 & 4.3 & 4.1 & 4.16669 & 6.19800 \\
\hline 2 & 15 & 3 & -10 & 4.2 & 4.6 & 4.3 & 4.36667 & 6.40155 \\
\hline 3 & 15 & 5 & -15 & 5.2 & 5.1 & 5.3 & 5.20000 & 7.16000 \\
\hline 4 & 30 & 1 & -10 & 4.2 & 4.5 & 4.1 & 4.26667 & 6.30090 \\
\hline 5 & 30 & 3 & -15 & 5.7 & 5.6 & 5.3 & 5.53333 & 7.53003 \\
\hline 6 & 30 & 5 & -5 & 5.6 & 5.2 & 5.9 & 5.56667 & 7.45600 \\
\hline 7 & 45 & 1 & -15 & 5.9 & 6.2 & 6.0 & 6.03333 & 7.80556 \\
\hline 8 & 45 & 3 & -5 & 7.5 & 7.8 & 7.4 & 7.56667 & 8.79007 \\
\hline 9 & 45 & 5 & -15 & 8.0 & 8.0 & 9.0 & 8.33333 & 9.20818 \\
\hline \hline
\end{tabular}

Where trial 1, 2, and 3 represent adhesion strength in $\mathrm{KN}$.

\section{$\underline{\text { Response table for } \mathrm{S} / \mathrm{N} \text { ratio }}$}

Table (2) was used to obtain response table for $\mathrm{S} / \mathrm{N}$ ratio (Larger is better) in order to determine which factor has strongly significant effect on the adhesion force of the coating layer, the data of such table illustrated in table (5).

Table (5) Response Table for S/N Ratio

\begin{tabular}{|c|c|c|c|}
\hline Level & Al\% & $\begin{array}{c}\text { Coating } \\
\text { thickness(mm) }\end{array}$ & Temperature(C) \\
\hline 1 & 13.17 & 13.54 & 14.93 \\
\hline 2 & 14.12 & 15.08 & 14.61 \\
\hline 3 & 17.20 & 15.88 & 14.96 \\
\hline Delta & 4.03 & 2.35 & 0.35 \\
\hline Rank & 1 & 2 & 3 \\
\hline
\end{tabular}

From table 3 it has been shown that the percentage addition of aluminum powder has a high delta value (4.03) with rank1. Coating thickness has secondly significant effect on the adhesion force with rank 2 and (2.35) delta value. Finally temperature has weakly significant effect on the adhesion force. 


\section{Main effect plot of S/N ratio}

Data carried out in table 3 are used to plot main effect plot for signal to noise ratio[10], from which it has been shown that the high adhesion force was achieved at level 3 for all factors as shown in fig. (2)

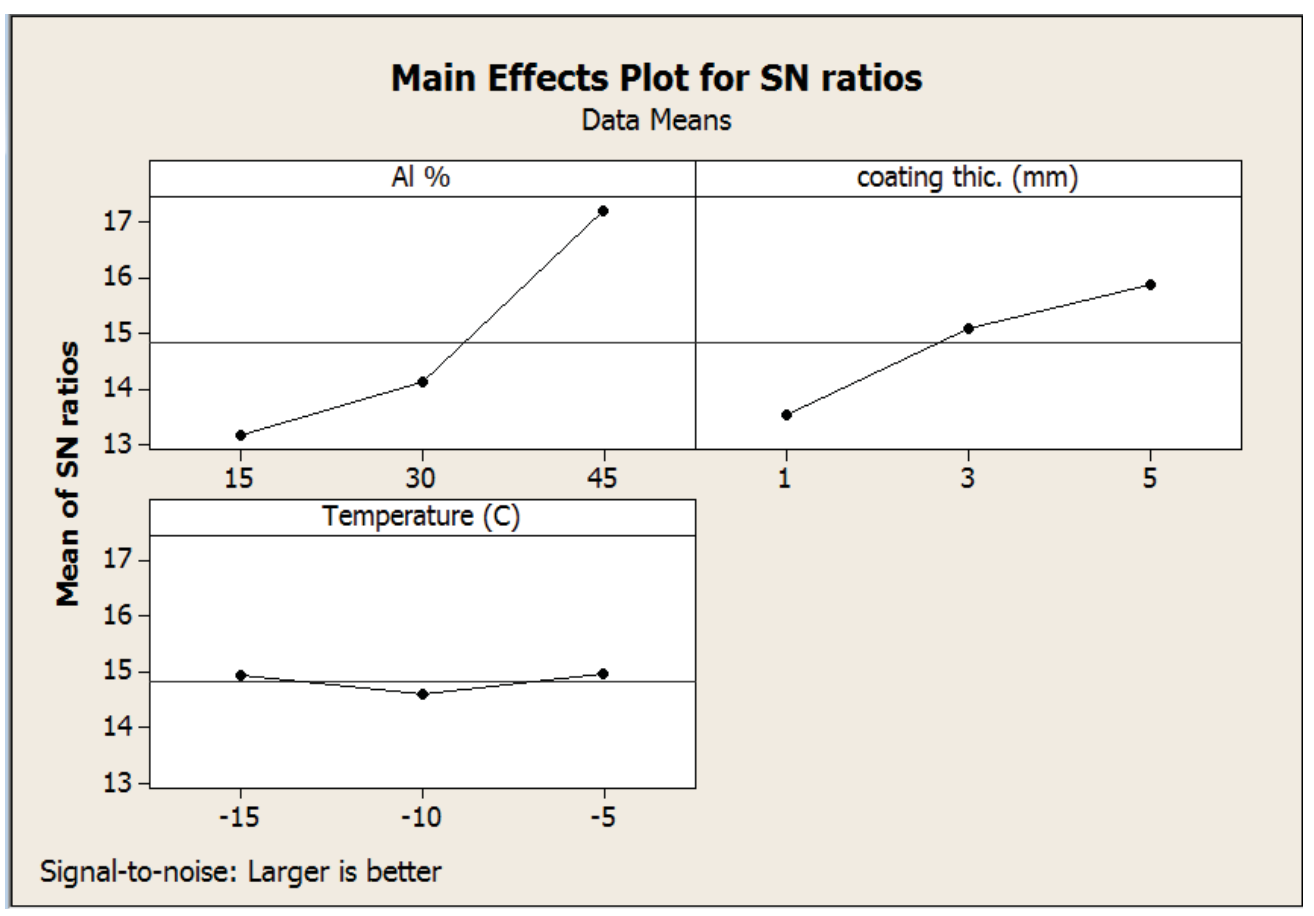

Fig. (2) Main effect plot for signal to noise ratio

\section{Analysis of variance ANOVA:}

General regression analysis was used to evaluate the effect of two factors on the adhesion force, as shown in table 6 .

Table (6) Analysis of Variance

\begin{tabular}{|c|c|c|c|c|}
\hline Source & DF & Seq. ss & F & P \\
\hline Regression & 4 & 15.700 & 11.950 & 0.0170 \\
\hline $\mathrm{Al} \%$ & 1 & 11.210 & 4.001 & 0.116 \\
\hline $\mathrm{Al} \%{ }^{*}$ coating thickness. & 1 & 3.962 & 0.406 & 0.560 \\
\hline $\mathrm{Al} \%{ }^{*}$ temperature & 1 & 0.0108 & 0.743 & 0.440 \\
\hline Coating thickness*temperature & 1 & 0.508 & 1.550 & 0.301 \\
\hline
\end{tabular}




\section{Predictive Model Generation}

Predictive model was built by using Minitab $16 /$ general regression analysis as the experiments are considered multiple control factors (three control factors). General regression is part of statistical that deals with the investigation of the relationship between the control factors and their interactions and the required response [11,12]. The regression model can be expressed by the following equation:

$$
\begin{gathered}
\text { Mean }=2.01966+0.106105 \mathrm{Al} \%+0.00480507 \mathrm{Al} \% * \text { coating thic. }(\mathrm{mm})+ \\
0.0021764 \mathrm{Al} \% * \text { Temperature }(\mathrm{C})-0.0229344 \text { coating thic. }(\mathrm{mm})
\end{gathered}
$$

*Temperature $(\mathrm{C})$

\section{Confirmation experiments:}

The above experimental analysis, main effect plot for $\mathrm{S} / \mathrm{N}$ ratios show that the maximum adhesion force can be obtain with the following conditions presented in table 7

Table (7) Optimal design conditions

\begin{tabular}{|c|c|}
\hline Factor & Best level \\
\hline $\mathrm{A} 1 \%$ & 45 \\
\hline Coating thickness $(\mathrm{mm})$ & 5 \\
\hline Temperature & -15 \\
\hline
\end{tabular}

Three experiments were performed under the optimal conditions in order to validate the optimization, from which it has been shown that the results of confirmation experiments and the predicted by optimization procedure are considered to be valid based upon the results of Taguchi experiments and within the $92.28 \%$ confidence interval.

\section{Conclusion}

Coating of low carbon steel by layer consists of (50 micron) aluminum powder mixed with ethyl silicate as a binder was performed in this study. The coating layer showed excellent resistance against the bending operation as well as at temperature below zero Celsius degree centigrade. Percentage aluminum added and thickness of coating layer, play an important role in the adhesion of coating layer on the substrate surface. Taguchi/ ANOVA optimization assists to obtain high adhesion force of the substrate coating, and confirmation experiments revealed that the optimal adhesion force obtained under optimal factors conditions. the results of confirmation 
experiments and the predicted by optimization procedure are considered to be valid based upon the results of Taguchi experiments and within the92.28\% confidence interval. The results obtained from the study indicate that the coating layer is suitable for the lining of the steel containers. 


\section{References}

1. Kenneth B. Tator, KTA-Tator, 2003 Coating Deterioration, Inc.ASM Handbook, Volume $5 B$.

2. C.H. Hare, Paint Film Degradation: Mechanisms and Control, Society of Protective Coatings, Pittsburgh, PA, 2001, p 311, 318-319

3. "Surface Preparation of Soluble Salt Contaminated Steel Substrates Prior to Coating," NACE Technical Committee Report 6G186, NACE International, March 2010.

4. G.Wypch, 2003, Handbook of Material Weathering, 3rd ed., ChemTec Publishing, Toronto, Ontario, Canada, p 58.

5. J. Wozniak, Development of a Compressed Hydrogen Gas Integrated Storage System (CH2-ISS) for Fuel Cell Vehicles, Hydrogen, Fuel Cells, and Infrastructure Technologies, FY 2003 Progress k “c (ULSD), Hypotheses Investigation”, Battelle Memorial Institute, September 5, 2012

6. H. Tang, S. Salley, K. Ng, Fuel Properties and Precipitate Formation at Low Temperature in Soy-, Cottonseed-, and Poultry Fat-Based Biodiesel Blends, Fuel 87 (13-14), 30063017, Oct. 2008.

7. F. Schüth, B. Bogdanovic, M. Felderhoff, September 2004, Light Metal Hydrides and Complex Hydrides for Hydrogen Storage, The Royal Society of Chemistry.

8. Hussain M. Yousif, Niveen J. Abdul kader, Wafaa M. Salih, Payman S. Ahmed, Comparison Study Between Hot Dip Galvanizing Steel And Coated Steel Used In Oil Storage Tank And Oil Pipe Transportion, International Conference on Environmental Impacts of the Oil and Gas Industries: Kurdistan Region of Iraq as a Case Study 17-19 April, 2017.

9. William G., 2006, Engineering statistics Handbook, http//www.itl.nist.gov 2011.

10. S. Fraley, et. al., "Taguchi methods: orthogonal arrays the michigon chemical process dynamic and controls open text book, USA.

11. Markham, "Analysis of variance (ANOVA)" Text Book http://www.csse.monash.edu.au., 2001.

12. Stephaine Fraley, et. al., "Design of experiments via taguchi methods: orthogonal arrays", 2013. 